\title{
A SOCIAL ECONOMY AND SUSTAINABILITY: IS THERE POTENTIAL FOR AN INTERFACE? ${ }^{1}$
}

\author{
Rochelle le Roux \\ BJuris LLB LLM PGDip LLM PhD \\ Professor, Faculty of Law \\ University of Cape Town \\ Director, Institute of Development and \\ Labour Law
}

\section{SUMMARY}

South Africa is plagued by high unemployment, extreme poverty and a worrying skills deficit. Job creation strategies focus on the formal economy, but some argue that the focus should shift to policies that would help with the expansion and development of the social (or solidarity) economy that exists alongside the public and private sectors. This sector is driven mainly by a concern to better the interests of their members, or to fulfil a public benefit, rather than to maximize profits. It has been argued that cooperatives provide a suitable vehicle for organizing workers in this sphere.

Jackson (Prosperity Without Growth, 2011), in advancing the idea of a sustainable economy, calls for macro-economic interventions that, inter alia, include a structural transition to service-based activities and working-time policies aimed at the facilitation of shared work. The former strategy (structural transition to service-based activities), although developed in a completely different context, shares many synergies with the underlying notions associated with the development of a social economy. It evolves around business models providing services which are resourcelight, but which are not the same as the service sector development which, worldwide, is associated with a concomitant decline in the primary and secondary sectors.

The article explores, first, the potential of the social economy as a site for the creation of decent jobs and the possible role in this regard of structures such as cooperatives and, second, whether any meaningful lessons can be drawn in this regard from the research that has be done on the "greening" of economic growth.

\section{INTRODUCTION}

This article explores the potential of the social economy as a site for the creation of employment, more specifically work in South Africa and also the possible role that structures such as co-operatives can play in this regard. This is done by taking cognisance of the emerging meaning of "decent work" and the apparent inability of the South African economy to create sufficient formal employment. It is argued that the creation of decent work is probably This is an adapted version of a paper presented by the author at the inaugural conference
of the Labour Law Research Network, Barcelona, Spain (June 2013). 
better served if approached via the sustainability lens, rather than by focusing on the creation of formal employment in the narrow sense. (The terms "formal" and "informal" are used loosely to indicate levels of public chronicling and regulation, such as licensing, tax registration, UIF registration, workmen's compensation registration, access to public dispute resolution structures etcetera. The more (or less) formal the activity, the more (or less) the levels of public chronicling and regulation associated with the activity.)

I am not suggesting that stable (formal) employment is not an important feature of a successful economy. It is, and for that reason we should continue to find ways of preserving and stimulating such employment. However, in the South African context and acknowledging that the broad and diverse range of the activities in the informal sector may demand different responses, one way of involving the many unemployed and uneducated people in the economy might be to first encourage and accommodate informal productive activities, rather than to focus on their absorption into formal employment as an immediate or even intermediate goal. In other words, sustainable work, regardless of formality, might be a better framework within which to develop policies for work/job creation, particularly for those dependent on subsistence living.

The structure of the article is as follows. In the next paragraph South African labour market numbers are briefly highlighted and I explain why I question current job creation initiatives. In paragraph 3 the notion of sustainable work and its interface with decent work is explored and developed. In paragraph 4 the potential of the social economy as a site for decent (and sustainable) work is examined, and in paragraph 5 some preliminary remarks are made about the role that sustainability can play in policy making. This is followed by a conclusion.

\section{THE SOUTH AFRICAN LABOUR MARKET AND THE PROSPECTS OF FORMAL EMPLOYMENT}

Job creation strategies in South Africa should be seen against the backdrop of some dismal labour market numbers. Out of a South African labour force of about 18 million persons, and including discouraged work seekers, around 34 per cent or 6,8 million persons of working age are unemployed. Even more disturbing, of the 6,8 million unemployed, 4,5 million are between the ages of 15 and $34 .^{2}$

Another important statistic is the extent of informal employment. Although it seems lower than expected, the Stats SA Surveys suggest that approximately 2,1 million persons, or 15 per cent of those who are in

\footnotetext{
These numbers are put in perspective if one considers that the population of the Western Cape, one of the more economically successful provinces in South Africa, according to the 2011 census, is estimated to be 5,8 million. Statistics South Africa "Census in Brief" (2011) http://www.statssa.gov.za/Census2011/Products/Census_2011_Census_in_brief.pdf (accessed 2012-12-06).
} 
employment, are employed in this sector. ${ }^{3}$ To a certain extent this can be blamed on lack of entrepreneurship, lack of skills and lack of access to credit, but some of the blame should fall on the structure of the economy, which complicates market access:

"Most manufactured or processed goods bought by poor people are massproduced in South Africa's core economy and are easily accessible in even the most remote spaza shops. This limits the opportunities for small-scale manufacturing of products that target poor consumers, which is the market environment that new entrepreneurs understand best. For this reason, local economic development strategies in other countries often focus on promoting an approach described by Philip as 'local production for local consumption' (2010a:7). In South Africa, however, a lack of viable opportunities for smallscale manufacturing of consumption goods aimed at poor consumers contributes to the bias in favour of retail activity in South Africa's informal sector, including street trading, spaza shops and shebeens" (references omitted).

Unemployment has many causes, but it is fair to say that it is primarily due to both a poor education system (and consequently low skills levels) ${ }^{5}$ and the inability of the South African economy to create sufficient jobs despite some growth. Such growth has been sluggish, and the reasons for this are many. ${ }^{6}$ Despite ambitious plans to address these challenges, it is difficult, particularly in the short term, to see how and where the many unemployed, and in particular the uneducated, will become formally employed.

The most prominent of these strategies is the National Development Plan 2030 (NDP), ${ }^{7}$ which is supplemented by a host of governmental programmes. ${ }^{8}$ The combined aim of these plans, among other things, is to visualize and strategize for an increase in employment levels over the next twenty years. In fact, the proposals in NDP are aimed at creating 11 million new jobs and reducing unemployment to about 6 per cent by 2030. While these aims are laudable, and while I do not dispute the need to implement at

3 This number is disputed by some and has been estimated to be as high as 6,3 million. See Adcorp "Adcorp Employment Index, May 2012" (11 May 2012) http://www.adcorp.co.za/ln dustry/Documents/11\%2006\%202012\%20Adcorp\%20Employment\%20Index\%20Report.pdf (accessed 2012-06-06) 4.

4 Philip "The Rationale for an Employment Guarantee in South Africa" 2012 29(1) Development Southern Africa 177. Nonetheless, informal retail appears to be a growing source of employment and represents 35\% of employment in the non-motor retail sector, equally about 180000 jobs in the period 1995-2009. Bhorat and Mayet "Employment Outcomes and Returns to Earnings in Post-Apartheid South Africa" (November 2012) http:// www.dpru.uct.ac.za/sites/default/files/sites/default/files/DPRU\%20WP12-152.pdf (accessed 2013-04-04) 9.

5 In a recent report of the World Economic Forum the quality of the South African education system is ranked 140 out of 144 and the quality of the maths and science education is ranked 143 out of 144 . See World Economic Forum "The Global Information Technology Report 2013" (2013) http://www3.weforum.org/docs/WEF_GITR_Report_2013.pdf (accessed 2013-05-30) 261.

6 See generally Bhorat and Mayer http://www.dpru.uct.ac.za/sites/default/files/sites/default/ files/DPRU\%20WP12-152.pdf for a discussion of the key drivers of employment trends in South Africa.

7 http://www.info.gov.za/view/DynamicAction?pageid=623\&mylD=348761 (15 August 2012) (first accessed 2013-01-14).

8 Such as the New Growth Path, Accelerated and Shared Growth Initiative for South Africa and the Industrial Policy Action Plan (IPAP 2013/14-2015/16). 
least some of the strategies proposed in these programmes, some of the assumptions underlying these strategies must be questioned.

First, while the NDP acknowledges the changing nature of employment and in particular the demise of what is commonly referred to as standard employment, the plan appears to be fixated with full employment as the ultimate goal. ${ }^{9}$ Hence, apart from a few superficial changes to labour market regulation, there appears to be no intention to amend labour legislation (which is essentially based on the standard employment model) to accommodate the changing and contingent nature of modern employment and to embrace the wider concept of work. Second, while the NDP stresses the need for sustainable livelihoods, the plan appears to regard employment as the only means of achieving this goal, and there is very little consideration of stimulating alternative means of work (such as self-employment) to realize this goal. ${ }^{10}$ Third, the NDP regards the service (retail, business and finance) sector as holding the biggest potential for the creation of new jobs and claims that:

"[w]hile the rest of the economy has expanded by 67 percent since 1994, the finance sector output has tripled, and was an important contributor to employment expansion. About 300000 to 400000 people work in finance, insurance and related activities. Substantial employment is created indirectly, through property, building management, security, personal and business services."

The reality is that the recent growth in this sector is distorted by the growth of labour brokers and cleaning and security services. ${ }^{12}$ In other words, the jobs now considered to be part of the services sector, more specifically the finance sector, are in fact not new jobs and were previously performed by a core business; as a result of externalization many of these jobs have merely migrated to another sector. ${ }^{13}$ While there is potential for job creation in this sector, it is doubtful whether it would be at the (misleading) tempo of recent years.

The NDP also regards agriculture in the rural areas as a major site for employment creation and anticipates that a "well-implemented strategy to boost agricultural output could create up to 1 million jobs by 2030". ${ }^{14}$ This is unlikely and an extremely unrealistic target. First, the recent almost doubling of minimum wages in the agricultural sector is expected to result in largescale retrenchments and mechanization, and is likely to stunt job creation in this sector for many years. Second, unemployment in South Africa is spatially uneven with far higher levels of unemployment in the rural areas.

NDP (see fn 7 above) 112 and 155.

10 Theron and Perez "The Prospects of Decent Work in Municipal Services: Case Studies in Care Work and Waste Management" 20122 Institute of Development and Labour Law Monographs 4-5.

11 NDP (see fn 7 above) 150.

12 Bhorat and Mayet http://www.dpru.uct.ac.za/sites/default/files/sites/default/files/DPRU\% 20WP12-152.pdf 8 concludes that by 2011 employment in security services, cleaning and farm labourers (provided via an intermediary) represents approximately 810000 jobs.

13 Theron and Perez 4-5 (see fn 10 above).

14 NDP (see fn 7 above) 124. 
However, whereas "small scale manufacturing and small scale agriculture are two of the most important avenues through which poor people typically enter into market activity", ${ }^{15}$ the easy access to (cheap) mass-produced goods in the rural areas and the lingering effect of black people's limited access to land under the apartheid regime curtail the opportunity to enter the market through these means. ${ }^{16}$ Immense structural changes and time are required to address these obstacles.

While some of these strategies undoubtedly have merit, they hold very limited prospects for employment or any other forms of income-generating work over the shorter term. The much-mooted infrastructure development, the revival of the primary and secondary sectors, the maximizing of the (formal) services sector and the improvement of the education system will simply take decades. It was while grappling with this and with the question whether we should indeed look at the formal economy for the solution, that I became attracted to the views of Theron on the solidarity (or social) economy and its potential to address this dilemma. ${ }^{17}$

\section{SUSTAINABLE WORK/EMPLOYMENT}

Before examining the solidarity economy, I also need to acknowledge that my attraction to the solidarity economy was further prompted by the work of Jackson on sustainability and "prosperity without growth", a notion coined by Jackson that I discovered while contemplating the role of labour regulation in the Anthropocene - the new geological epoch which signifies the altering impact of humans on the earth's ecological systems. ${ }^{18}$ While contemplating the possible impact of labour regulation on the demise of the world's ecological systems, I wrote an exploratory paper on the interface between the role of labour law and sustainability, suggesting "that labour law should be approached through the lens of sustainable development and that it should become concerned with the notion of sustainable employment". ${ }^{19}$ However, with the benefit of hindsight, I now realize that, in unpacking a possible meaning for the notion of sustainable employment, I missed or minimized at least three important perspectives. First, my focus was, as is evident from the quote below, entirely on employment in the formal, corporate economy and how labour relations typically play themselves out in that arena and ignored the possible significance of sustainable employment for those who are not in formal employment:

\footnotetext{
Philip 2012 29(1) Development Southern Africa 178.

16 lbid.

17 See generally Theron and Perez (fn 10 above); Theron and Visser "Remember Me when your Ship comes in': Cooperatives and the Need to Shift from a Wage Culture" Institute of Development and Labour Law Monographs, University of Cape Town 1/2009; and Theron "Collective Self-Employment: Subsidise Co-ops before Companies" (2012-09-06) The Cape Times 9 .

18 Jackson Prosperity without Growth (2011).

19 Le Roux "The Purpose of Labour Law? Can It Turn Green?" in Malherbe and Sloth-Nielsen (eds) Labour Law into the Future (2012) 230231.
} 
"What does this imply for unions (and also employers), assuming that they do adopt the concept? Obviously unions will have to be more mindful of the environment in their day-to-day operations, but sustainability ought to become the basis of their decision-making and, more importantly, the basis on which they bargain. While the best and immediate financial interests of their members will probably remain at the top of the bargaining agenda for unions, the proposed approach will require all stakeholders to consider not only how the wage bargain can feed into sustainability, but also how the bargaining process can add value to all five capitals referred to earlier. This may mean including sustainability issues (in the deep green sense), but more specifically sustainable employment, on the bargaining agenda. The details of sustainable employment will have to be developed over time, but examples include employer subsidies for the use of public transport as an incentive for car owners to use public transport, incentives for other energy-saving techniques by employees (instead of a higher percentage remuneration increase), work/life cycle incentives, and avoiding demands (for example, remuneration increases) which are simply not sustainable in particular economic climates and that will inevitably, if agreed to, result in retrenchments and possibly encourage employers to mechanise where this was not necessarily planned. Sustainable employment may also mean developing social networks which advance social capital without necessarily advancing the wage bargain, such as training and education programmes for employees and even their families. Such an approach may also mean, if the transience of employment is indeed as intrinsic as suggested above, that it may be necessary to shift from employment security to employability as an underlying objective of employment (for example, re-skilling provided for by employers and employer assistance with post-employment schemes, such as the establishment of a co-operative that continues to provide a service to the employer). The important point is that sustainable employment will require all parties concerned to harness sustainability at many levels, including 'the self', 'the partnership' (employee/employer relationship) and 'the environment', and to abandon short-term goals for long-term benefits."

While these comments remain valid for those in standard formal employment (even if only on a temporary basis), they disregard a significant world of work that is developing under the influence of externalization and concomitant informalization, and where the traditional description and regulation of employment do not quite fit.

Second, I possibly approached the notion of sustainable employment via a green/ecological lens only and disregarded the broader agenda of sustainability, namely the need to meet the needs of the present without compromising the ability of future generations to meet their own needs. In other words, I limited my approach by focusing only on the impact of employment on the natural world, and I did not consider the relationship between employment/work on the totality of the major form of capital of wellbeing associated with sustainability, namely, nature, social/cultural, human and built capital. The green approach is important, but not the only lodestar of the sustainability discourse.

Third, in developing the notion of sustainable employment, I omitted to contemplate the role of the "decent work" agenda of the ILO.

20 Le Roux in Malherbe and Sloth-Nielsen (eds) Labour Law into the Future 242-243. 
I was, however, forced to rethink my initial (and admittedly limited) perception of sustainable employment after engaging more extensively with the decent work objective.

It is now more widely understood that the values of decent work apply to both workers and employees; in other words, to all forms of productive activity. The decency of work, or the lack thereof, depends on the realization of four core values, namely, the opportunity to work, the right to freedom of association, social protection, and voice. And while decent work might be achieved via the application of traditional employment legislation, employment legislation need not be the only conduit for the realization of decent work. This implies that the decency of work may mean different things in different contexts and that it cannot be measured in terms of indicators. ${ }^{21}$ It is therefore more useful to regard decent work as a continuum, with those workers and employees at the bottom suffering the most "decent work deficits" and those further up the continuum suffering fewer deficits. ${ }^{22}$ (Hence, for the rest of this article I distinguish between "work" performed by workers who are not necessarily in an employment relationship and "employment", meaning the narrow concept equating to a standard job to which employment legislation would ordinarily apply.)

However, Theron and Perez argue that work that does not meet the second, third and fourth objectives of decent work (these are rights at work, social protection and voice) is not sustainable and that we need to develop a concept of sustainable work that "incorporate[s] the social economy that exists unacknowledged alongside what is traditionally regarded as the public and private sector". ${ }^{23}$ This is consistent with the ILO thinking on the interface between decent work and sustainability:

"The world needs more and better jobs, especially in societies suffering from widespread poverty, and these jobs must have the quality of sustainability. Decent work for sustainable development means that in social terms, such jobs must be open to all equally and the related rewards have to be equitable. Inequality and discrimination provoke frustration and anger, and they are a recipe for social dislocation and political instability. Extending opportunities for decent work to more people is a crucial element in making globalization more inclusive and fair. In economic terms, jobs have to be productive and able to compete in a competitive market. And environmentally, they must involve the use of natural resources in ways that conserve the planet for future generations, ${ }_{24}$ while being safe for working women and men and for the community."

It was at this point that I noticed some differences with the views of Jackson, but also potential synergies.

\footnotetext{
Theron and Perez 6 (see fn 10 above).

Von Broembsen "Mediating from the Margins: The Role of Intermediaries in Facilitating Participation in Formal Markets by Poor Producers and Users" 2012 36(1) SAJLR 3137.

23 Theron and Perez 6 (see fn 10 above).

24 ILO "Toolkit for Mainstreaming Employment and Decent Work" (2008) http://www.ilo.org/ wcmsp5/groups/public/---dgreports/---exrel/documents/publication/wcms_172612.pdf (accessed 2013-05-05) vii.
} 
It is difficult to do justice to Jackson's work in a few paragraphs, but it essentially calls for a shift to an economic model that focuses on sustainable human well-being rather than focusing on GDP-based measures of progress, since "[t]hese measures largely ignore the value of natural and social capital and the distribution of wealth and income" and "misleadingly count natural capital depletion and many human and social costs as economic gain". ${ }^{25}$ It is important to understand that this approach goes further than the one advocated by the green economists, who claim that many of the pending ecological dangers can be addressed by taxing the depletion of natural resources (for instance, by imposing carbon taxes) and more efficiency, while growth (and the way that it is measured) continues as before. ${ }^{26}$ More specifically, Jackson and the proponents of this view call for a fundamental shift in economic thinking that focuses on growth that is measured in terms of sustainable well-being and not in terms of material consumption. This shift will require recognition that:

- natural resources are finite and that sustainable well-being can simply not be measured in terms of material consumption;

- the goal of limitless growth must be replaced with the goals of material sufficiency, equitable distribution and sustainable well-being;

- the world's economy be reconceptualized with the aim of preserving ecological systems.

For the purposes of this article I am focusing on only one of the avenues of intervention in the regulation of employment advanced by Jackson that could assist with the goal of sustainable well-being, namely, resisting labour productivity growth by focusing on income-generating activities where efficiency does not add value in the same way as in the productive sectors. A second avenue of intervention, the sharing of work, is not dealt with in this article.

\section{Resisting labour productivity growth ${ }^{28}$}

Labour productivity is seen as an essential ingredient of profit-making. But increased productivity depends on technological innovation and this, in turn, is directly linked to the use of more natural resources, particularly fossil fuels. But higher productivity presents a threat to employment: as productivity increases and labour inputs decline, fewer people are needed for the same

25 Costanza, Alperovitz, Daly, Farley, Franco, Jackson, Kubiszewski, Schor, Victor and Colman "Building a Sustainable and Desirable Economy-in-Society-in-Nature" (2012), http://sustainabledevelopment.un.org/content/documents/Building_a_Sustainable_and_Desi rable_Economy-in-Society-in-Nature.pdf (accessed 2013-05-06) vi.

26 Jackson Prosperity without Growth 68-96.

27 Costanza et al http://sustainabledevelopment.un.org/content/documents/Building_a_Sustain able and Desirable_Economy-in-Society-in-Nature.pdf vii.

28 Jackson Prosperity without Growth 128-133. Also see Jackson and Victor "Productivity and Work in the 'Green Economy': Some Theoretical Reflections and Empirical Tests" 20111 Environmental Innovation and Societal Transitions 101; and Jackson "Beyond the Growth Economy" 2009 13(4) Industrial Ecology in Europe 487. 
outputs. Unless the economy continues to grow, unemployment will follow and will ultimately lead to less spending and less demand for produced goods. This, in broad strokes, is the essence of the productivity trap. The reduced use of resources that follows will be welcomed by the ecologist, but the impact on the social well-being of the unemployed will be disastrous. Although a reduction in labour productivity, whether engineered or by happenstance, is likely to be too much to bear for those preoccupied with GDP growth as a key to jobs, Jackson nonetheless asks whether a reduction in productivity does not possibly present an opportunity.

Such a suggestion may well be frowned upon by many. In fact, it seems to contradict the ILO position on the role of productivity in the creation of decent work:

"The employment-displacing effects of productivity growth cannot be avoided in some instances. However, in the longer term and at the aggregate level there is not necessary trade-off between productivity growth and employment growth in a country. Productivity gains can work their way through the macro economy so that job losses in one location or sector may be compensated by job gains in another area or sector. The activities of multilateral agencies can directly or indirectly impact on labour productivity. They can, for example, improve education and training of the workforce or they can provide advice on the links between productivity, growth, and employment."

However, on closer inspection it is clear that Jackson has very specific types of services in mind, such as services where the value of the product is in the quality of the service rendered. While acknowledging that some services (for example retail distribution and hospitality services) remain material- and carbon-intensive, he argues that there are many services for which communities will have always a need, that are not resource intensive and that present a natural opportunity for reduced productivity growth. Put differently, there are many services that essentially revolve around human needs, cannot be "stockpiled", become "degraded" through trade and cannot be "delivered by machines" (or where they can be delivered by machines, human input can achieve the same result). ${ }^{30}$ These include services such as "community-based social enterprises, community energy projects, slow food co-operatives, sports clubs, community health and fitness centres, gardening, local repair, maintenance and refurbishment services, craft workshops, writing centres, community music and drama, local training and skills, hairdressing, gardening and conservation". ${ }^{31}$

While these enterprises represent a kind of "Cinderella economy" that is out of sight of the consumer society and are often not even regarded as economic activities, they are not only labour-intensive, but, importantly from an ecological point of view, offer few prospects for labour productivity growth. Thus, while going against the grain of conventional economics, this

29 "Toolkit for Mainstreaming Employment and Decent Work" (2008) http://www.ilo.org/wcmsp5/groups/public/---dgreports/---exrel/documents/publication/wcms_ 172612.pdf (accessed 2013-05-05) 16.

30 Jackson "Let's be Less Productive" 26 May 2012 New York Times http://www.nytimes.com/ 2012/05/27/opinion/sunday/lets-be-less-productive.html?_r=0 (accessed 2013-05-04).

31 Jackson Prosperity without Growth 130. 
(Cinderella) services sector, in theory at least, offers an opportunity to maintain employment in a non-growing economy without increasing the environmental impact. However, Jackson realizes that material well-being is a key to prosperity and he accepts that economic growth is still essential to poor and developing economies. His views are therefore aimed at developed economies, not at the likes of the South African economy. Nonetheless, it is difficult to see how the consumer-obsessed developed economies, unless perhaps forced into it by a cataclysmic global economic or ecological meltdown, will adopt an approach consistent with this thinking. Yet, while barely counting in formal terms in one economy, does this approach not provide the prospects of not only work, but also decent work, in another? In other words, environmental impacts aside, does this sector not hold the same potential for work in a non- or slow-growing developing economy?

\section{THE SOCIAL ECONOMY: A SITE FOR DECENT AND SUSTAINABLE WORK?}

The social economy is a third sphere of activity that exists on the margins of the public and private sector, and has been defined to include all economic activities conducted by enterprises, primarily co-operatives, associations and mutual benefit societies, that aim to produce goods, provide services and knowledge while pursuing both economic and social aims and fostering solidarity. ${ }^{32}$ Thus, while one should be careful not to limit the ambit and meaning of the social economy, it will normally involve activities that revolve around human social needs rather than the production of a material product. This implies services that most people will instinctively classify as municipal services, but which municipalities, mostly because of a lack of resources, would not always be able to perform. (The first element of the word "municipality" in fact means "service performed for the community".)

These attributes of the social economy show remarkable alignment with Jackson's Cinderella economy.

The social economy comprises non-profit organizations, but also not-forprofit organizations that, although engaged in some economic activity, are not in the first instance obsessed with the generation of profit, but rather with the establishment of a sustainable productive activity that has communal benefits. $^{33}$ It is suggested that this sphere might become increasingly relevant in a context where, as a result of externalization, prospects of direct employment in both the private and public sectors are diminishing and work, if it exists, is performed either intermittently and/or via a third party such as a labour broker.

However, even if we accept that this sphere can be a site for labourintensive practices, a concern would be whether it can also accommodate

32 Defourny and Develtere "The Social Economy: The Worldwide Making of a Third Sector" in Defourny, Develtere and Fonteneau (eds) L'économie Sociale au Nord et au Sud (1999) 25-36 as quoted by Theron and Visser 14 (see fn 17 above).

33 Theron and Visser 13-14 (see fn 17 above). 
the objectives of decent work. Accepting that decent work represents a continuum, upgrading the decency of these jobs may also not necessarily imply formalizing those jobs, nor meeting labour standards in the traditional sense. What might then be the best vehicle for the delivery of decent work in the social economy?

Workers involved in a typical social economy activity, despite some similarities with workers in an employment relationship, are generally selfemployed workers who earn their living by their own efforts and cannot rely on the regularity of income associated with waged employment. Not only might their priorities differ, but the typical platforms for the delivery of decent work in standard (formal) employment (such as trade unions, collective bargaining, minimum standards legislation) are unlikely to be effective in this environment. ${ }^{34}$ However, co-operatives, the organizing mechanism typically associated with the social economy, potentially offer a more appropriate bargaining platform for a collection of self-employed persons:

"To the extent that it is possible to bargain collectively on behalf of the selfemployed, it seems more appropriate to conceive of this bargaining within an entrepreneurial paradigm, in which it is one of a number of strategies the association devises to promote each member's economic interest.'

and

"Because a cooperative aims to meet the needs of its members, rather than to maximise profits, it is able to provide services that a company would not consider profitable. For the same reason it is able to retain members in employment in circumstances in which a company would not. Cooperatives can also be utilised flexibly, to enhance the income of the self-employed. Workers who are self-employed or employed may form cooperatives to enhance their income in a part-time activity or to provide social protection."

Furthermore (and importantly), co-operatives also have the potential to counter the more invidious consequences of externalized work by eliminating the middleman and by providing an enterprise that prioritises the economic (and also social) needs of its members.

A good example of such an activity in the social economy is (informal) recycling. ${ }^{37}$ The point was made earlier that the green economy and green jobs are often embraced simply as a means of growing the economy in GDP terms and that we should be careful not to equate a growing green sector with a strategy on climate change and sustainability. ${ }^{38}$ However, waste management and recycling is an example of a sector that, in addition to its green attributes, relates to human needs (clean and healthy environment) and is potentially labour-intensive, and therefore is important in terms of job

34 Theron and Perez 27 (see fn 10 above).

35 Theron and Visser 12 (see fn 17 above).

36 Theron and Visser 13 (see fn 17 above).

37 Theron and Perez 11-15 (see fn 10 above).

38 See Stevis "Green Jobs? Good Jobs? Just Jobs? US Labour Unions Confront Climate Change" in Räthzel and Uzzell (eds) Trade Unions in the Green Economy (2013) 179191 and also 186-191 where the potential unjust impact of green jobs is unpacked. 
creation. ${ }^{39}$ Currently only a small percentage of South Africa's plastic waste is recycled and there is thus huge potential for job creation. Some may argue that automated methods may be more efficient (and if GDP is the only goal, automation might indeed be the only option), but in the context of high unemployment, strategies that yield similar results and are labour-intensive must surely be prioritised. Waste management and recycling is essentially a municipal responsibility, ${ }^{40}$ but it is difficult to see how, with current fiscal constraints, municipalities will be able to take ownership of recycling, in particular. ${ }^{41}$ For the time being, it is more likely that recycling will remain an externalized function. This presents an opportunity for the social economy.

In the context of recycling the following possible benefits of this model are identified by Theron and Perez:

- "The elimination of a chain of sub-contractors and the middle men that results from engaging large contractors to provide recycling services, and that leaves workers at the bottom of the chain vulnerable.

- The opportunity for local actors to take their own economic development in hand.

- More effective minimisation, on the assumption that not-for-profit enterprises should be willing to recycle products that would not be considered profitable by for-profit firms.

- Increased levels of participation in the separation of different recyclables, on the assumption that all sections of the community would support projects properly motivated, if they were also seen as creating employment.'

The recycling sector, based on its close interface with the environmental and sustainability discourse and its potential labour intensity, is an easy and obvious example to use. The same can be said of, for example, water and other conservation programmes. But there are many areas in the South African context related to human well-being (an acknowledged pillar of sustainable development) where services (human input) are arguably even more critical than in the case of the examples already cited. These include care work (children, the sick and the elderly), basic safety, food security, education support and the maintenance of rudimentary roads. ${ }^{43}$ And while it can be argued that these services are essentially municipal services, these authorities, for the reasons already cited (such as fiscal), are unlikely to take ownership of these responsibilities in the short term.

Admittedly, some of these activities are already the focus of the Community Work Programme, which is not an employment guarantee, but it

39 UNEP "Promoting Decent Work in a Green Economy, ILO Background Note to Towards a Green Economy: Pathways to Sustainable Development and Poverty Eradication" (2011).

40 National Environmental Management: Waste Act 59 of 2008.

41 Theron and Perez 18 (see fn 10 above).

42 Generally see Theron and Perez (see fn 10 above).

43 The need for these services is for several reasons more manifest in South Africa than one would expect at first. For instance, car theft and car break-ins for petty theft are part of everyday South African life (and almost certainly driven by unemployment); the need to care for the young and elderly, made more pronounced by a high prevalence of single parent households and the consequences of the HIV/Aids pandemic, complicates the work/life balance of those who can work. 
does provide the prospect of regular part-time work. ${ }^{44}$ While it is a government-funded programme, it still requires an enabling agent before it can be activated and in many rural areas it might indeed be the best way of providing these services. The same can be said of the Expanded Public Works Programme which entails public funded employment. While generally not associated with labour-intensive activities, the social sector is regarded as an exception and might indeed in some instances be a more appropriate vehicle for the delivery of low output, but labour intensive social economic activities. ${ }^{45}$ However, in the absence of such an intervention, co-operatives provide an ideal and sustainable platform from which to launch these muchneeded (extended municipal) services.

International experience does suggest that co-operatives can be sustainable only within a systematic and supportive framework. It is in this regard that co-operatives have had two false starts in South Africa: Under apartheid co-operatives mainly served to promote the white agricultural sector. While the Co-operatives $\mathrm{Act}^{46}$ resulted in an unprecedented growth of new co-operatives, the lack of ongoing support resulted in an extremely high mortality rate, and by 2009 only 2644 or 12 per cent of the 22619 cooperatives on the register were still operational. ${ }^{47}$ Clearly, more than good legislation and attractive incentive schemes is required to ensure the sustainability of co-operatives, and it is for this reason that the Department of Trade and Industry (DTI) has developed a strategy aimed at the ongoing promotion, support and development of the co-operative sector. ${ }^{48}$ The necessary legislative amendments and regulations will hopefully be finalized by the end of 2013. However, while the future of the co-operative sector looks much brighter as a result of this strategy, one reservation in respect of the DTI strategy is that it seems to see the co-operative sector primarily as a vehicle for the creation of employment, and not much attention is (or appears to be) given to its potential as a host of decent work that does not necessarily take the form of employment.

Returning to the notion of decent work, it appears that the social economy might not only present work opportunities, but can also realize the remaining values of decent work. The nature of co-operatives embodies at least the notion of voluntary organization through which the collective is given voice. Without these qualities, it would indeed be hard to say that an entity is a cooperative and that the remaining value of decent work, namely social protection, will depend entirely on how well this collective voice is exercised. Can it arrange some benefits that were previously not accessible (even if these do not correspond with what we expect in the case of standard employment)? (For example, can it provide or ensure protection against hazardous waste where there was previously no protection?) And further

44 Philip 2012 29(1) Development Southern Africa 180-182.

45 Ibid.

$46 \quad 14$ of 2005.

47 Department of Trade and Industry "Promoting an Integrated Co-operative Sector in South Africa 2012-2022" (2012) http://www.dti.gov.za/economic_empowerment/docs/coops/legis_ policy/coop-strategy.pdf (accessed 2013-05-15).

48 lbid. 
and importantly, can the co-operative manage and nourish the work opportunities presented in order to ensure its own sustainability?

I suspect that it is the need for social protection that will present the greatest challenge to the quest for decent work in the social economy, rather than the right to freedom of association. While work-based communities such as co-operatives can develop the capacity to be the custodians of at least some forms of social security, they might not be able to insulate their members completely against disruptions to economies. For that reason, they will probably function best in an environment where there is access to some level of social security (whether universal or contributory) not provided via the platform of employment. ${ }^{49}$

\section{PRELIMINARY REMARKS: IS SUSTAINABILITY THE NEW ETHOS FOR DECENT WORK?}

Does the fact that work is decent imply that it is also sustainable? Despite a close interface, decent work and sustainable work are probably not always the same thing. Decent work is key to sustainable work, but in order to be sustainable, work should, in addition to being decent, also have an element of longevity or durability. In other words, while not guaranteeing the regularity of income associated with waged employment, sustainable work should, at the micro level, hold the prospect of an "ongoing earnings floor", ${ }^{50}$ personal growth, and empowerment. ${ }^{51}$ What would be the most tenable outcome of a job creation policy: a decent informal job that is sustainable, or decent formal employment that offers a surge in income, but is of short duration?

One might therefore ask whether the journey towards decency and ultimately sustainability should necessary involve a progression towards formality, since informality might in fact be crucial to the sustainability of some work. For this reason, I must question the moves to criminalize informal work in South Africa through onerous licensing procedures for hitherto unlicensed activities, as proposed in the now-abandoned Street Vendors (Protection of Livelihood and Regulation of Street Vending) Bill, 2012, and the proposal in the Co-operatives Amendment Bill ${ }^{52}$ that members of worker co-operatives be deemed employees for purposes of labour legislation, unlike the position under the current Act. The latter amendment is aimed at stemming the practice of unscrupulous employers who are converting their operations to worker co-operatives in order to escape the operations of labour legislation. Obviously this cannot be tolerated, but it can be addressed at administrative level. Artificially extending the reach of employment legislation to forms of work which, conceptually cannot be equated to bilateral employment, in the hope that more workers would be

49 The best of example of this is a basic income grant. Also see Standing Work after Globalization: Building Occupational Citizenship (2009) 299-302.

50 A phrase used by Philip 2012 29(1) Development Southern Africa 185.

51 See Stevis in Räthzel and Uzzell (eds) Trade Unions in the Green Economy 188-189.

52 (B 17-2012). Also see the Co-operatives Second Amendment Bill (B18-2012). 
drawn into the net of protective legislation will only bring short-term relief and will ultimately push more and more workers into the wilderness of externalization.

Earlier, reservations were expressed about the NDP's vision, which regards rural agriculture as a major site for employment creation. However, the obstacles mentioned earlier (such as minimum wages and poor land distribution) might be less prominent if they were approached via the lens of decent work and sustainability, and if rural agriculture was seen as a social economic activity with rural food security as an objective. Also, since the social economy (or certainly aspects of it) will always need a champion to leverage some of its potential, and since its biggest potential lies in the rendering of municipal or quasi-municipal services, it is important that local authorities integrate social economy dynamics into their social and development plans and initiatives, as suggested by the 2009 ILO regional conference on the social economy. ${ }^{53}$

Finally, because of the nature of the social economy, there is limited danger that it will fall into the productivity trap and ought therefore to be sustainable at the macro level; it simple needs to be fostered. It is doubtful whether the same can be said of the industrial sectors, where the forces of capital are truly dominant, and more social engineering will be required to resist the capitalist temptation to replace workers with machines.

\section{CONCLUSION}

Even if the world can recover from the global recession, it is clear that it simply cannot be business, and for that matter, employment, as before. The ecological world can simply not sustain the levels of GDP growth that we saw before the recession and, whether we are ready or not, work and its regulation will have to be approached via a sustainability, rather than a growth, dynamic.

Whether the developed world, for the sake of sustainability, is ready to slow down and to settle voluntarily into a Cinderella economy, as proposed by Jackson, remains to be seen. Even Jackson admits that we simply do not know whether we can really make enough money from these activities to keep the economy going. Nonetheless, the notion of such an economy, quite apart from its sustainability dynamics, might contain the seeds of relative prosperity for emerging economies such as South Africa, which is struggling to overcome high levels of unemployment and inequality Granted, it might not be a solution for everybody functioning in the informal economy, but particularly for those at the subsistence end of the range of informal activities, it might hold the key to a sustainable livelihood. However, providing decent work in the Cinderella economy will require us to part ways with traditional notions of productivity and to accept that the values of decent

53 Plan of Action for the Promotion of Social Economy Enterprises and Organizations in Africa adopted at ILO Regional Conference: The social Economy - Africa's response to the global Crisis, Johannesburg (October 2009). 
work can be delivered via various means that might not even include waged employment.

Despite the potential prospects of the Cinderella economy in the developing world, such an economy still needs to be fostered and nurtured. Public employment schemes might be one potential vehicle in this regard. Another is co-operatives. Despite some shortcomings, the new co-operative legislation and regulation in South Africa is promising, but will still require a level of patronage by local government and sponsorship by national government. Ultimately, however, the Cinderella economy will require an understanding, in the words of Jackson, that the humble broom should be preferred to the leaf-blower. ${ }^{54}$

54 Jackson Prosperity without Growth 130. 